\title{
Comparison Between Effects of Standard Feed and Whole Wheat Supplemented Diet on Experimental Eimeria tenella and Eimeria maxima Infections in Broiler Chickens
}

\author{
By L. Waldenstedt ${ }^{1}$, K. Elwinger ${ }^{1}$, P. Hooshmand-Rad ${ }^{2}$, P. Thebo ${ }^{2}$ and A. Uggla ${ }^{2}$ \\ ${ }^{1}$ Department of Anımal Nutrition and Management, The Swedish University of Agricultural Sciences, and \\ ${ }^{2}$ Department of Parasitology, National Veterinary Institute and Swedish Unıversity of Agricultural Sciences, \\ Uppsala, Sweden
}

\begin{abstract}
Waldenstedt L, Elwinger K, Hooshmand-Rad, P, Thebo P, Uggla A: Comparison between effects of standard feed and whole wheat supplemented diet on experimental Eimeria tenella and Eimeria maxima infections in broiler chickens. Acta vet. scand. 1998, 39, 461-471. - The effects of experimental infections with Eimeria tenella (Experıment 1, $\mathrm{n}=144$ ) or E maxıma (Experıment 2, $\mathrm{n}=216$ ) in broller chıckens fed whole wheat, with or without access to grit, as compared to a standard pelleted feed were studied. Inclusion of whole wheat was gradually increased up to $30 \%$ at 3 weeks of age. Grit was given separately. The chickens were kept on litter in a parasite-free environment with free access to water and feed.

At 3 weeks of age half the number of chickens were individually inoculated with 500 sporulated oocysts of $E$ tenella (Experıment 1) or 3000 sporulated oocysts of Eimeria maxıma (Experıment 2), and the remaining birds were kept separate as uninfected controls Neither coccidiostats nor growth enhancers were used. Oocyst concentration was determıned from each group separately. Intestınal lesıons were scored on 6 birds per feed regime $7 \mathrm{~d}$ postınoculation, and on the remainıng birds at slaughter

Diet had no significant effect on bird performance during infection. However, there was an indication that the $E$ maxima infection had more negative effect on weight gain in birds given standard feed than in those given whole wheat supplement, but the difference was not significant $(p<0.09)$ The number of oocysts shed or mean intestinal lesion scores did not differ between diets in either experiment In both experiments, the number of Clostridium perfringens was higher in the caeca of inoculated birds, but there were no differences between diets
\end{abstract}

coarse structure; coccidiosis; parasites; broilers.

\section{Introduction}

Coccidiosis is a major health and production problem in the modern broiler industry. The disease is caused by a group of intracellular protozoan parasites of the genus Eimeria. Two of the most common and pathogenic species are E. tenella and E. maxima, which infect the intestinal cells lining the caeca and the small in- testine, respectively (Fernando 1990). Control of coccidiosis is mainly focused on the use and development of chemotherapy and vaccines, but today increasing attention is also being paid to nutritional factors with a possible capability of enhancing the chickens' ability to resist infections. 
Cummings (1992) reported a decreased oocyst output in Eimeria-infected chickens fed a high protein concentrate with whole wheat supplement as compared with a conventional broiler diet. This result was suggested to be due to a better developed gizzard, which was presumed to destroy the parasites. Whole wheat increases gizzard activity (Scholtyssek et al. 1983) and would possibly give a better natural resistance to coccidiosis. Feeding of whole wheat to chickens as a supplement to a standard pelleted feed is quite common in Denmark and Sweden as a means of decreasing feed costs.

In broiler chickens, subclinical coccidiosis is considered to be an important contributing factor in the development of necrotic enteritis ( $\mathrm{Al}$ Sheikhly \& Al-Saieg 1980, Baba et al. 1992), caused by the bacterium Clostridium perfringens. Coccidia can play a significant role in the development of the disease, as mucosal damage facilitates the establishment and multiplication of C. perfringens (Al-Shelkhly \& Truscott 1977). Branton et al. (1987) found that use of a feed with coarser particles led to decreased chicken mortality due to necrotic enteritis as compared with feed consisting of finer particles. The objects of the present experiments were to study oocyst output, the degree of intestinal lesions, and bird performance after an experimental infection of either $E$. tenella or $E$. maxıma in broiler chickens fed a coarse-structure diet including whole wheat and access to grit, as compared with a standard pelleted feed. We also wanted to study the effects of the different feeds on the invasion of $C$. perfringens in the chicken intestine possibly enhanced by a subclinical Eimeria infection.

\section{Materials and methods}

\section{Experiment 1}

The experiment included 144 unsexed Ross chicks delivered at day of hatch from a commercial hatchery. Birds were kept on wood shaving litter in pens $(1.50 \times 0.75 \mathrm{~m})$ in an Eimeria-free environment with free access to water and feed. The lighting regimen was $20 \mathrm{~h}$ light and $4 \mathrm{~h}$ dark. The sex ratio in each group was recorded on each weighing occasion.

The experiment comprised 3 different feeding regimens. Each feed treatment consisted of 6 groups of 8 chickens each. Birds were either fed a standard pelleted feed $(20.0 \%$ crude protein, Table 1), a standard feed supplemented with whole wheat $(11.2 \%$ crude protein), or a standard feed supplemented with both whole wheat and granular grit $(2-3 \mathrm{~mm})$. The grains in the standard feed were hammer-milled using a 5 $\mathrm{mm}$ screen. The feed was steam pelleted $(3 \mathrm{~mm}$ diameter pellets). During the 1st week, pellets were rolled before being given to the chickens. Whole wheat was included in the standard feed at a rate of $10 \%$ from 1 week of age, $20 \%$ from 2 weeks and $30 \%$ from 3 weeks unt 1 l slaughter. Grit was given separately in free access from 1 week. Neither growth-promoting substances nor coccidiostats were used. Birds were slaughtered at $44 \mathrm{~d}$ of age without prior starvation. A single species isolate of E. tenella, originally isolated from an outbreak of clinical coccidiosis in Swedish layers and passaged through chickens 3 times previously, was used as inoculum. The oocysts were recovered after propagation in 3-week-old Eimeria-free chickens ( $E u$ ropean Commission, 1995), and sporulated and stored in $2 \%$ potassium dichromate at $4{ }^{\circ} \mathrm{C}$ for 1 month before inoculation. At 3 weeks of age, half the number of chickens ( 3 groups of each feed regimen) was individually inoculated with a water suspension of 500 sporulated oocysts of $E$. tenella directly into the crop. The dose was chosen so as not to cause severe clinical signs. Uninoculated birds were kept separate from infected birds and served as control groups. Faecal samples were collected prior to inoculation for analysis of possible presence of oocysts. From 6 days post-1noculation (p.i.), faeces were 
collected daily from each group separately on a metal plate $(40 \times 40 \mathrm{~cm})$ put on the litter $24 \mathrm{~h}$ prior to collection. Samples were analysed for number of oocysts per gram of faeces using a standard McMaster technique (European Commission 1995).

One week p.i., 1 bird from each group (i.e., 6 birds per feed regimen) was chosen at random, and killed and examined for intestinal lesions using a score from 0 to 4 , where score 4 indicates the most severe damage of the intestinal mucosa according to Johnson \& Reid (1970). At slaughter all remaining birds were examined as above, and the total score for the birds of each feed regimen was averaged over the number of birds. Scrapings of intestinal mucosa were examined microscopically for coccidial organisms (European Commission 1995). For analysis of the contents of $C$. perfringens one caecum was taken from all birds killed 1 week p.i. and from 2 birds per group at slaughter. The caeca were removed immediately using aseptic techniques, transferred to sterile Petri dishes and stored for a maximum of $2 \mathrm{~h}$ at about $4{ }^{\circ} \mathrm{C}$ before microbiological examination. Determination of $C$. perfringens was carried out according to the Nordic Committee on Food Analyses (Anonymous 1985), but excluding the use of a sporulation medium for identification. When fewer than 10 colony forming units (cfu) $/ \mathrm{g}$ of caecal contents were found this was recorded as $5 \mathrm{cfu} / \mathrm{g}$.

Bird weights and feed consumption were recorded, and the feed conversion ratio was calculated. Gizzards were collected at slaughter, emptied, trimmed of excess fat, and weighed. Necropsies were performed on all birds that died unintentially during the experiments.

\section{Experiment 2}

The experiment included 216 unsexed chickens obtained as in Experiment 1, equally distributed over 3 different feeding regimes in the same
Table 1. Composition and calculated nutrient content of the standard feed fed to broller chickens.

\begin{tabular}{lc}
\hline Ingredients & $\%$ \\
\hline Feedstuffs & \\
Wheat & 46.0 \\
Barley & 18.3 \\
Oats & 10.0 \\
Soybean meal & 10.0 \\
Rapeseed meal & 5.0 \\
Fish meal & 4.0 \\
Meat and bone meal & 2.0 \\
Vitamins and trace elements premix & 1.0 \\
Calcium carbonate & 0.7 \\
Sodium chloride with 1odıne & 0.2 \\
Dicalcium phosphate & 0.3 \\
Anımal fat & 2.0 \\
DL-methionıne & 0.2 \\
L-Lysıne HCl & 0.3 \\
& \\
Calculated nutrient content, \% & \\
Metabolizable energy, MJ/kg & 12.0 \\
Crude protein (analysed) & 20.0 \\
Fat & 4.0 \\
Lysine & 1.1 \\
Methionıne & 0.51 \\
Calcium & 0.95 \\
Phosphorus & 068 \\
Sodium & 0.15 \\
\hline &
\end{tabular}

way as in the previous experiment. Each feed treatment comprised 6 groups of 12 chickens. Birds were slaughtered at $36 \mathrm{~d}$ of age. Methods used and analyses performed were in accordance with the previous experiment. When 3 weeks old, the birds were inoculated with 3,000 sporulated oocysts of E. maxima. Oocysts were obtained as in Experiment 1. In this experiment faecal samples were collected twice weekly. Bird weights and feed consumption were recorded prior to inoculation and at slaughter. Carcass percentage was calculated. Gizzards were not collected.

\section{Statistical analyses}

Statistical analyses were based on analysis of variance, using the General Linear Models pro- 
cedure of $\mathrm{SAS}^{\circledR}$ (SAS Institute Inc. 1989), with feed, inoculation, and sex ratio as main effects. No significant differences due to sex ratio were found for any of the traits, and this effect was excluded from the model. In order to analyse differences between treatments, Fisher's protected least-significant-difference test was used. Relatıve frequencies for mortality were angularly transformed before statistical analyses according to Snedecor \& Cochran (1968).

\section{Results}

\section{Performance}

Throughout Experiment 1 no significant differences in live weight or feed conversion ratio between inoculated and uninoculated birds were found, Table 2 . In the uninoculated groups, chickens given whole wheat and grit had a lower $(\mathrm{p}<0.01)$ live weight at slaughter (44 d) than chickens given standard feed. At slaughter, uninoculated birds given whole wheat and grit tended to have a lower accumulated feed intake than uninoculated birds fed standard feed $(p<0.02)$ or whole wheat without grit $(p<0.06)$. Due to spillage, grit intake could not be measured.

In Experıment 2, average live weight at slaughter (36 days) was higher for uninoculated than for inoculated chickens $(p<0.006)$, Table 3 . There were no significant differences in live weights of chickens fed the different diets. Uninoculated birds had a better feed conversion ratio $(p<0.03)$ at slaughter than inoculated

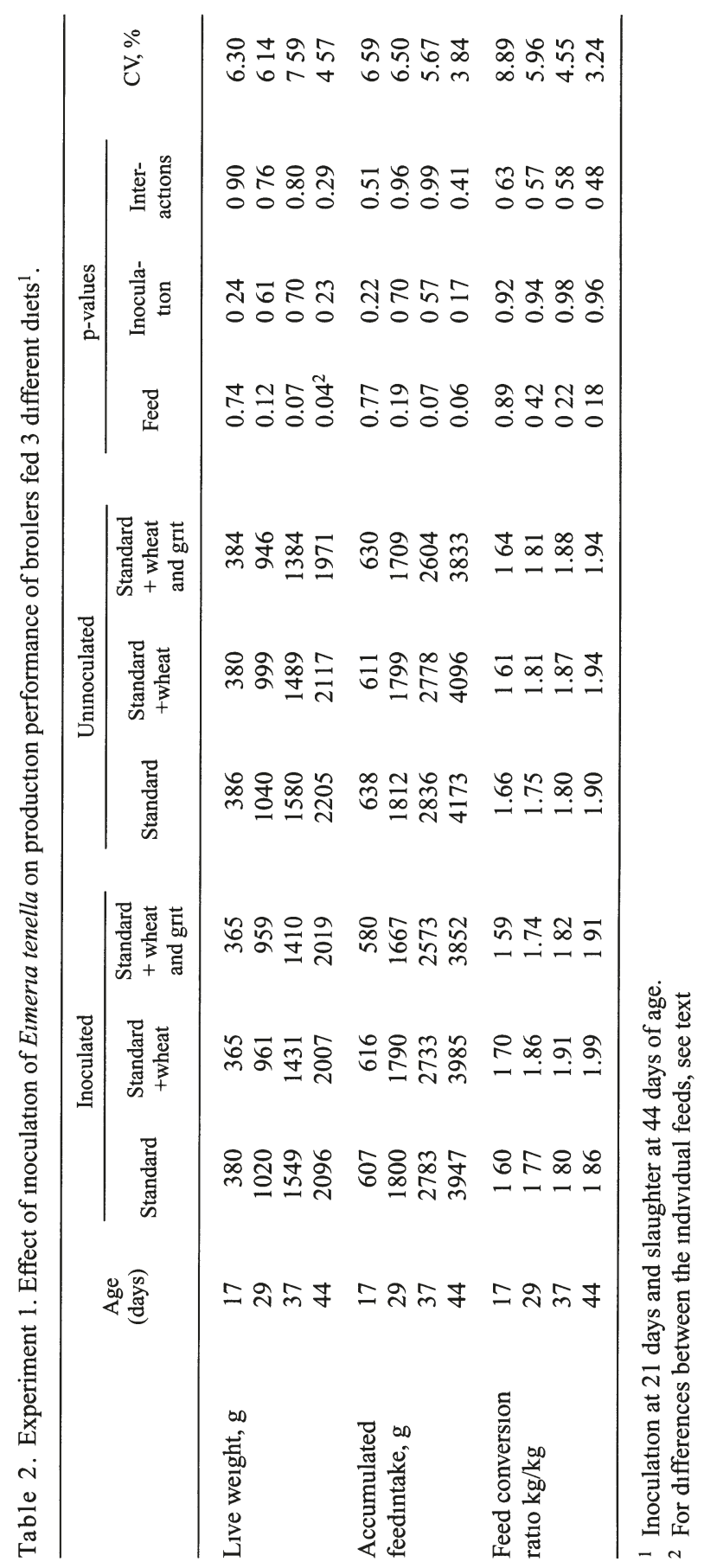




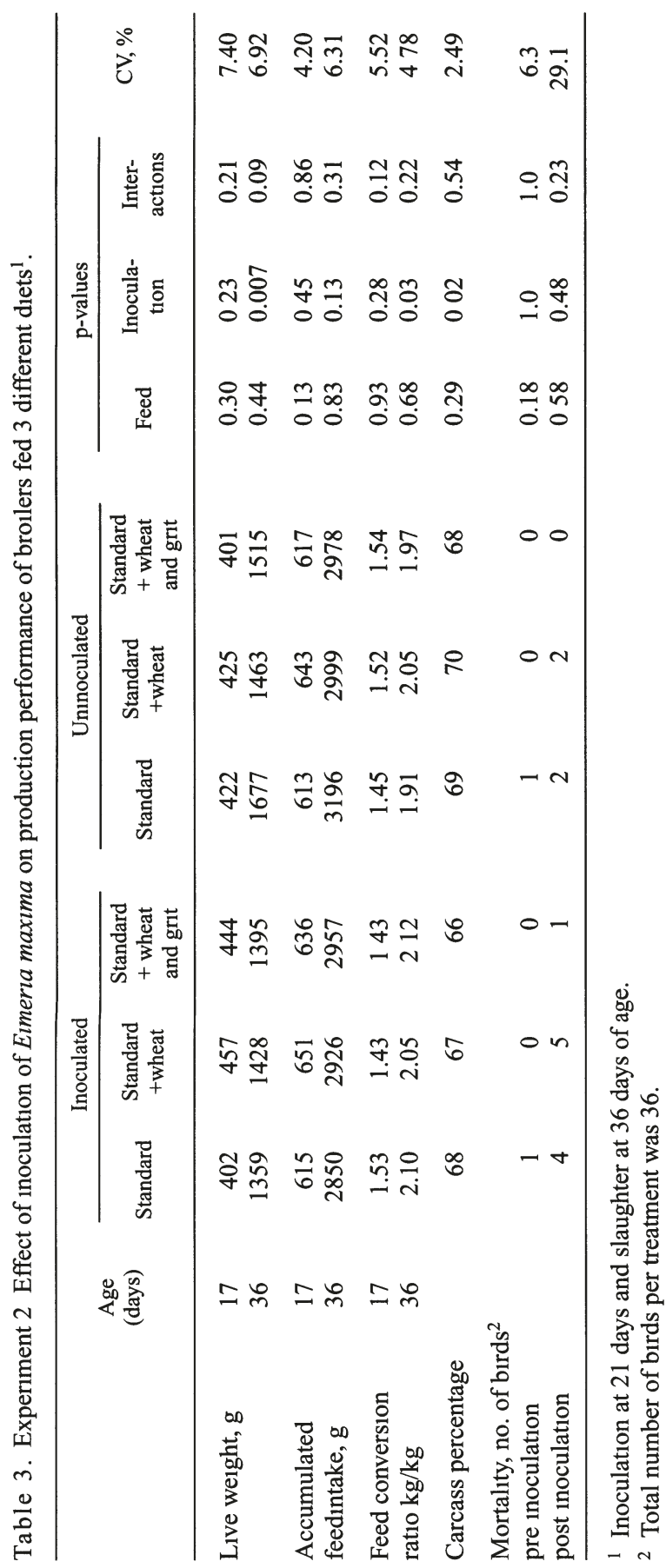

birds. Also carcass percentage was higher in uninoculated birds $(p<0.02)$. Further, there were no significant differences in feed intake, feed conversion ratio or carcass percentage between the different diets. Sex ratio had no significant effect on any of the parameters measured in either experiment.

In Experiment 1 birds given whole wheat had a lower live weight from 37 days $(p<0.03)$ up to slaughter $(p<0.02)$ than birds not given whole wheat. Feed conversion ratio were significantly higher at 37 days $(p<0.004)$ for birds given whole wheat, but not so at slaughter $(\mathrm{p}<0.17)$. In Experiment 2 there was no significant differences in performance between birds given whole wheat or not.

\section{Disease and mortality}

In Experiment 1, E. tenella-inoculated chickens showed no clinical signs of disease, even though examination showed haemorrhages in the caeca of most of the examined birds 1 week p.1. However, one of the inoculated birds died 6 days p.i., and autopsy showed caecal coccidiosis. Two other inoculated chickens died 3 weeks p.1., and necropsies revealed circulatory failures. In the uninoculated groups no birds died during the experiment.

In Experiment 2 some of the E. maxima-infected birds showed diarrhoea and distress starting 5 days p.i. Altogether, 10 inoculated birds (9.2\%) unintentionally died p.i. as compared with 4 uninoculated birds (3.7\%). Deaths in the infected group occurred 


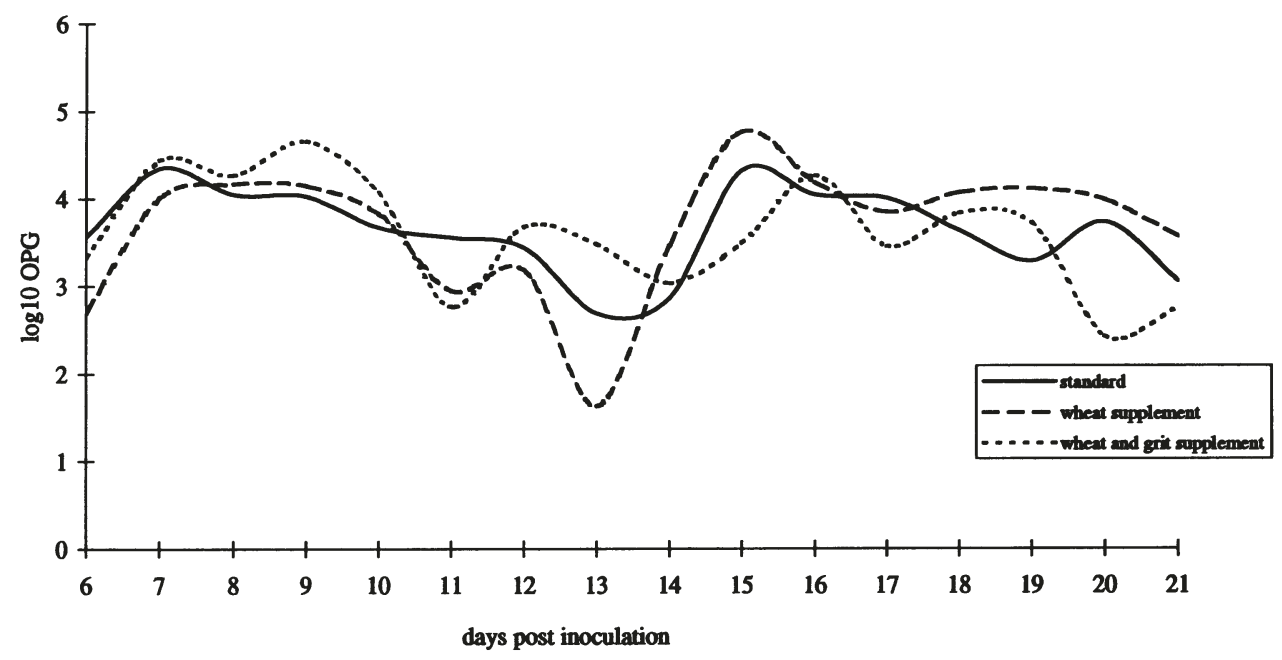

Figure 1. Experiment 1. Eimeria tenella. Oocysts per gram faeces (OPG) in inoculated broilers fed 3 different diets.

between 5 and 7 days p.i., whereas deaths in the control groups were more evenly distributed during the experimental period. Microscopical examinations of intestinal mucosa from dead birds revealed coccidial infection with a few oocysts, but mainly a high number of large rodshaped bacteria, resembling Clostridium. Necropsies showed ascites in all dead uninoculated birds.

\section{Oocyst output}

In both experiments, only inoculated birds shed Eimeria oocysts, and all excreted oocysts morphologically resembled the inoculated species. No oocysts were detected prior to inoculation. There were no significant differences in oocyst output between the groups of chickens given the different feed regimes in either of the experiments (Figs. 1 and 2).

\section{Lesions}

In Experiment 1, there were no differences in intestinal lesion scores between inoculated and uninoculated birds, either 1 week p.i. or at slaughter, Table 4. In some birds, blood was observed in the ceaca. However, lesion scores were generally lower $(\mathrm{p}<0.01)$ at slaughter than 1 week p.i. There were no differences between birds given different feeds.

In the second experiment, birds inoculated with $E$. maxima showed a higher intestinal lesion score 1 week p.i., than uninoculated controls $(p<0.04)$, Table 5. There were no differences between diets. At slaughter there were no differences between inoculated birds and controls, or between diets. In both experiments, lesions were mainly found in the midgut from duodenum past the yolk sac diverticulum.

\section{Clostridium perfringens}

In Experiment 1, all examined birds were positive for $C$. perfringens. Cfu per gram caecal contents was slightly lower in birds inoculated with $E$. tenella than in uninoculated birds 1 week p.i., but the difference was not statistically significant $(p<0.06)$, Table 4 . In birds inoculated with $E$. maxima cfu per gram caecal contents were higher in inoculated than in uninoc- 


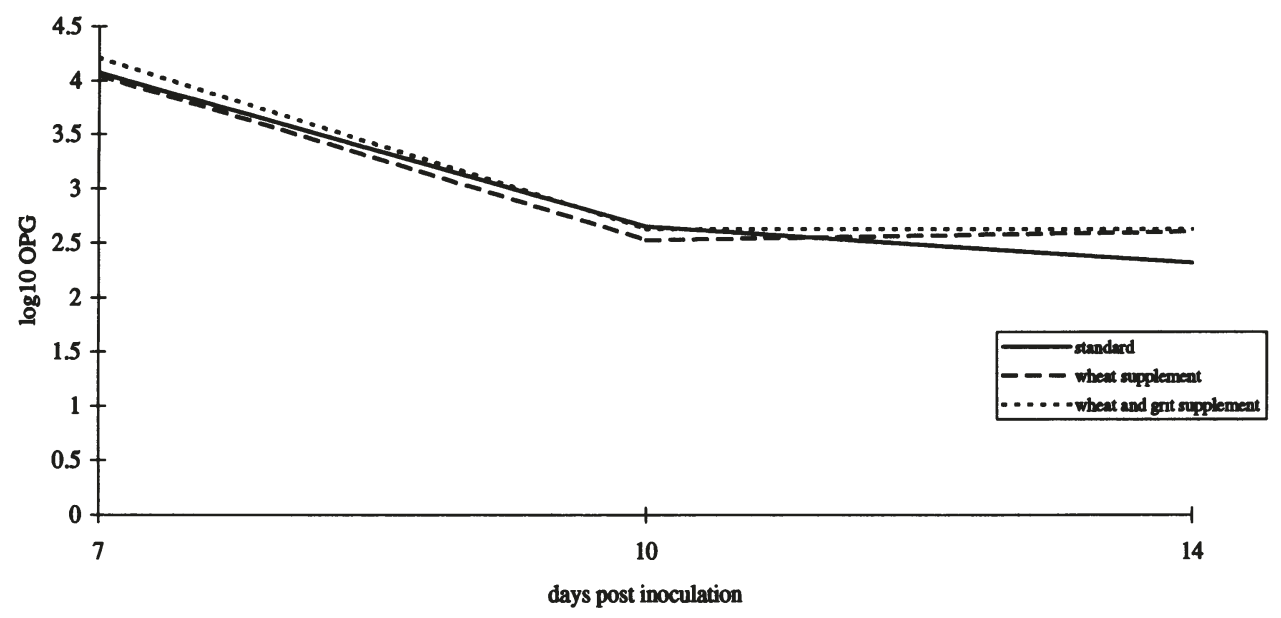

Figure 2. Experiment 2. Eimeria maxima. Oocysts per gram faeces (OPG) in inoculated broiler chickens fed 3 different diets.

ulated birds at d $28(\mathrm{p}<0.01)$, Table 5. At slaughter there were no differences between inoculated and controls in either of the experiments. No differences were found between diets.

\section{Gizzards}

The weight of the gizzards in Experiment 1 (Table 4) was higher for chickens fed whole wheat $(p<0.003)$ and whole wheat and grit $(p<0.006)$ than for chickens fed only standard feed. Also the gizzard weight expressed as percentage of body weight was higher for chickens given whole wheat with or without access to grit $(\mathrm{p}<0.02)$. There were no differences in gizzard weights between inoculated and uninoculated chickens.

\section{Discussion}

The inoculation doses used in the experiments were relatively low, which would simulate a subclinical level of infection. It was anticipated that if no positive effects of diets were found in a low dose inoculation, no benefits could be expected during a severe infection.

Body weight changes were applied as an indication of diet effects on the severity of the coccidial infection. Weight gain is normally not affected, or only slightly reduced, during mild Eimeria infections (Conway et al. 1993). The induced infection of $E$. maxima slightly impaired bird performance in the experiment. Not only weight gain, but also feed conversion ratio and carcass percentage were negatively affected. The infection seemed to have less negative effect on weight gain in birds given whole wheat as compared with groups fed only standard feed, but differences were not statistically significant. Weight gain between inoculation and slaughter in inoculated birds, compared with uninoculated controls, was $81 \%$ for chickens given standard feed, compared with $98 \%$ for birds given standard feed and whole wheat, and $92 \%$ when given standard feed and both wheat and grit supplement. The E. tenella infection did not affect bird performance. Higher doses of oocyst inocula are probably needed to 
impair performance (Conway et al. 1993). Oocyst shedding in birds inoculated with $\mathrm{E}$. tenella showed peaks at 7-9 days and 14-16 days p.i., implying a reinfection. Birds inoculated with E. maxima, which were slaughtered at an earlier age ( 36 days vs 44 days), showed only one peak in the oocyst output 7 days p.i. Thereafter the shedding decreased, but it never ceased completely during the 2week experimental period. The number of oocysts shed did not differ between birds given different diets in either of the experiments. These findings contradict results by Cummings (1992), who reported a marked decrease in oocyst shedding in birds given whole wheat supplement relative to those fed only a standard pelleted feed. Whole grain feeding increased gizzard size, and thus gizzard activity. A larger grain intake that further increases gizzard size might be needed to ensure the desired anticoccidial effect, but it should also be considered that, among other stimuli, the grinding action of the gizzard plays an important role in breaking up the oocysts and thus triggering the release of sporocysts and sporozoites (Fernando 1990). This implies that the findings of Cummings may not have been caused by increased gizzard activity due to whole wheat feedıng, but possibly by other dietary factors.

An Eimeria infection increases the prevalence of C. perfringens. Al-Sheikhly \& AlSaieg (1980) found a significant difference in mortality rates due to necrotic enteritis between birds infected with E. acervulina and birds infected with $E$. necatrix before infection with $C$. perfringens, which indicates that there might be a difference between Eimeria species in this respect. In our study, birds inoculated with $E$. tenella tended to have lower levels of $C$. perfringens 1 week p.i. in comparıson with controls, however the differences were not statistically different. This

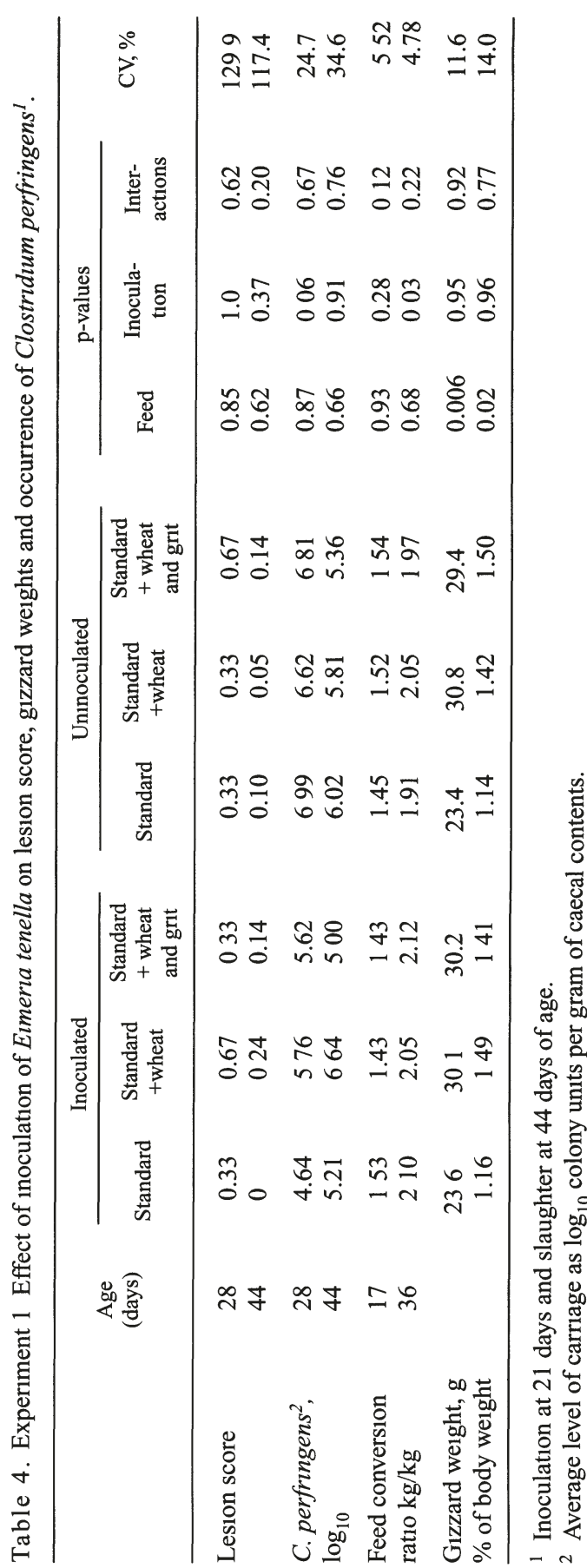

Acta vet scand vol 39 no 4, 1998 
finding contradicts Baba et al. (1992), who showed that an $E$. tenella infection made the birds more receptive to clostridial infection. At slaughter, there were no differences between inoculated and uninoculated birds. Birds inoculated with $E$. maxima had higher levels of $C$. perfringens than uninoculated birds 1 week p.i., but again there were no differences at slaughter. Stutz \& Lawton (1984) have shown an inverse correlation between number of $C$. perfringens and weight gain in broiler chickens. Whether the weight gain of $E$. maxima-inoculated chickens in this experiment was affected by the Eimeria infection, by an increased prevalence of $C$. perfringens, or by other changes of the intestinal microflora caused by the infection, is not clear.

Lesion scores are frequently used to assess the severity of coccidial infections (Johnson \& Reid 1970). However, Kaldhusdal \& Hofshagen (1992) showed that subclinical intestinal diseases other than coccidiosis may also produce intestinal lesions in broiler chickens. These lesions may erroneously be considered to be caused by coccidia in a lesion scoring technique unless microscopical examination for oocysts and endogenous stages of the parasites is performed (Johnson \& Reid 1970). According to Johnson \& Reid (1970) scoring of birds with an E. maxima infection may be difficult to interpret, as the degree of pathogenıcity does not always correlate with the severity of the lesions, but Conway et al. (1990) found a modest decrease in weight gain with increasing lesion scores in an E. maxima infection. In the present study, inoculation with $E$. tenella did not significantly result in specific lesions in the caeca, whereas some unspecific lesions were observed in the small intestine. This result indicates that only a mild $E$. tenella infection was established. In birds inoculated with E. maxima, lesion scores 7 days p.i. were higher in inoculated birds than in uninoculated controls. One week 
later, at slaughter, scores were generally lower and no differences between inoculated and uninoculated chickens were seen. No coccidia were detected at the microscopic examination of intestinal scrapings at slaughter, suggesting that inoculated birds had recovered and that the lesions observed may have been due to other factors.

In conclusion, in the present experiments whole wheat supplementation, with or without grit, did not have a significant effect on the performance of broiler chickens experimentally infected with $E$. maxima or E. tenella. Even though the E. tenella infection did not affect chicken live weight, there was no positive effects of whole wheat supplement on oocyst shedding or intestinal lesion scores.

\section{Acknowledgements}

We thank Dr. Oddvar Fossum, the National Veterinary Institute, for lesion scoring and necropsies, the Department of Food Hygiene, the Swedish University of Agricultural Sciences for clostridial analyses and Dr. Anna Lundén, the National Veterinary Institute, for valuable comments.

Economic funding was obtained by the Swedish Farmers' Foundation for Agricultural Research, and in part by the National Board of Agriculture and the Swedish Council for Forestry and Agricultural Research.

The study was part of the EU research collaboration COST 820.

\section{References}

Al-Sheikhly $F$, Truscott RB: The interaction of Clostridium perfringens and its toxins in the production of necrotic enteritis of chickens. Avian Dis., 1977, 21, 256-263.

Al-Sheikhly F, Al-Saieg A: Role of coccidia in the occurrence of necrotic enteritis in chickens. Avian Dis., 1980, 21, 241-255.

Anonymous - Nordic Committee on Food Analyses, NMKL Method No. 95: Clostridium perfrıngens - determination in foods, 2nd edition, Ord and Form, Uppsala, Sweden. 1985.
Baba E, Wakeshıma H, Kazunori F, Fukata T, Arakawa $A$. Adhesion of bacteria to the caecal mucosal surface of conventional and germ-free chickens infected with Eimeria tenella. Am. J. Vet. Re., 1992, 53, 194-197.

Branton SL, Reece FN, Hagler WM Jr. Influence of a wheat diet on mortality of broller chickens associated with necrotic enteritis. Poultry Sci., 1987, 66, 1326-1330.

Conway DP, McKenzle ME, Dayton AD. Relationship of coccidial lesion scores and weight gain in infections of Eimeria acervulina, E. maxima and E. tenella in broilers. Avian Pathol., 1990, 19, 489-496.

Conway DP, Sasal K, Gaafar SM, Smothers CD Effects of different levels of oocyst inocula of Eimeria acervulina, E. tenella and E. maxıma on plasma constituents, packed cell volume, lesion scores, and performance in chickens. Avian Dis., 1993, 37, 118-123.

Cummings $R B$. The biological control of coccidiosis by choice feeding. Proc. XIX World Poultry Congr., 1992, Vol. 2, 425-428.

European Commission: EUR 16602 - Guidelınes on technıques in coccidiosis research. Eds. J. Eckert, R. Braun, M. W. Shirley and P. Coudert. Office for Official Publications of the European Communities, Luxembourg. 1995.

Fernando MA: Eimeria: infections of the intestıne. In: P. Long (ed). Coccidiosis of Man and Domestic Anımals. CRC Press, Boca Raton, Florida, USA. 1990, 64-72.

Johnson J, Reid WM: Anticoccidial drugs: Lesion scoring technıques in battery and floor-pen experıments with chickens. Exp. Parasitol., 1970, 28, 30-36.

Kaldhusdal M, Hofshagen M: Barley inclusion and avoparcin supplementation in broiler diets. 2 . Clinical, pathological and bacterological findings in a mild form of necrotic enteritis. Poultry Sci., 1992, 71, 1145-1153.

Parish WE: Necrotic enterits in the fowl. 1. Histopathology of the disease and 1solation of a strain of Clostridium welchil. J. Comp. Pathol., 1961, 71, 377-393.

SAS Institute $\cdot$ SAS/STAT ${ }^{\circledR}$ Users' Guide, Version 6, 4th edition, Volume 2, SAS Institute, Inc., Cary, North Carolina, USA. 1989.

Scholtyssek S, Seeman M, Seeman, $G \cdot$ Growing capacity and carcass quality in brotlers after choice feeding (I. Report), 1983, 47, 166-174. (In German). 
Snedecor GW, Cochran WG: Statistical Methods, 6th edition. Iowa State University Press, Ames, Iowa, USA. 1968.

Stutz MW, Lawton GC: Effects of diet and antimicrobials on growth, feed efficiency, intestınal Clostridium perfringens and ileal weight of broiler chicks. Poultry Sci., 1984, 63, 2036-2042.

\section{Sammanfattning}

Effekten av helt vete på experimentella koccidieinfektioner hos slaktkycklingar.

I 2 försök $\left(n_{1}=144, n_{2}=216\right)$ studerades följderna av experimentella koccidieinfektioner hos slaktkycklingar som getts helt vete, med eller utan tillgång till granitgryn, i jämförelse med kycklingar som fătt ett pelleterat standardfoder. Veteinblandningen ökades gradvis upp till $30 \%$ vid 3 veckors ålder. Kycklıngarna hölls i en från början parasitfrı mıljö med fri tillgång till foder och vatten. Granitgryn gavs separat 1 fri tillgång. Fodret innehöll varken foderantibıtika eller koccidiostatika.

Vid 3 veckors ålder inokulerades hälften av kycklingarna individuellt med 500 sporulerade oocystor av $E$. tenella (försök 1) eller 3000 sporulerade oocystor av E. maxima (försök 2), och de återstående oinokulerade kycklingarna hölls separat som kontroll. Antalet utsöndrade oocystor bestämdes för varje grupp separat. Tarmlesioner graderades på 6 kycklıngar per foder (varav hälften oinokulerade) 1 vecka efter nokuleringen, och på alla återstående kycklingar vıd slakt.

Hos kycklıngar inokulerade med $E$. maxima tenderade djur som fă̊tt tillskott av helt vete att ha en mindre viktförlust än djur som fătt standardfoder $(p<0.09)$. Tillskott av helt vete påverkade inte tıllväxten hos kycklıngar inokulerade med E. tenella. Antalet utsöndrade oocystor eller grad av tarmslesioner orsakat av koccidierna påverkades inte av fodret i något av försöken. I båda experimenten var förekomsten av Clostridium perfringens högre hos inokulerade djur, men det var ingen påverkan av foder.

(Recelved May 22, 1997; accepted August 28, 1998).

Reprints may be obtained from: L. Waldenstedt, Department of Animal Nutrition and Management, The Swedish University of Agricultural Sciences, S-755 97 Uppsala, Sweden. E-mail: Lotta.Waldenstedt@huv.slu.se, tel: +46-18-671000, fax: +46-18-674501. 
